\title{
Acorns of introduced Quercus rubra are neglected by European Jay but spread by mice
}

\author{
J. Bieberich, M. Lauerer, G. Aas
}

Bieberich J., Lauerer M., Aas G., 2016. Acorns of introduced Quercus rubra are neglected by European Jay but spread by mice. Ann. For. Res. 59(1): 249-258.

Abstract. Northern Red Oak (Quercus rubra L.; native in North America) is regarded as an invasive species in Central Europe, where it is the most common non-indigenous broad-leafed tree species in forestry. The species' impact on native ecosystems and thus its future management are discussed controversially. Because dispersal is an important step in an invasion process, we studied whether European Jays (Garrulus glandarius L.) and mice, both main dispersers of native oaks in Europe, mediate the dispersal of Q. rubra seeds. Morphological characteristics of Q. rubra and native $Q$. robur L. acorns were quantified according to their implications for dispersal. We tested experimentally whether and to what extent mice and jays collect acorns of both oak species and if their behavior depends on choice options (dual choice vs. no-choice). Acorns were offered on feeding platforms, controlled by scouting cameras. Results showed that Q. rubra acorns have a thicker pericarp, a rounder shape and a higher dry weight compared to acorns of $Q$. robur. In the behavioral assays jays avoided acorns of $Q$. rubra if they were offered together with those of $Q$. robur (dual choice) as well as when $Q$. rubra acorns were offered alone (no-choice). This selection behavior could be caused by the differences in morphological traits observed between the acorns of the two species. In contrast to jays, mice took acorns of both oak species likewise indicating that seed morphology does not affect the attractiveness of Red Oak acorns for rodents. In conclusion, Quercus rubra is collected by animals in Central Europe to a considerable amount but dispersal should be restricted to moderate distances mediated by mice, leading mainly to stabilizing and increasing existing populations rather than founding of new ones.

Keywords Northern Red Oak, invasive plant species, acorn morphology, seed dispersal, acorn selection experiment, European Jay, mice

Authors. Judith Bieberich (judith.bieberich@uni-bayreuth.de), Marianne Lauerer, Gregor Aas - Ecological-Botanical Gardens, University of Bayreuth, Universitätsstraße 30, 95447 Bayreuth, Germany.

Manuscript received February 02, 2016; revised April 20, 2016; accepted April 27, 2016; online first June 01, 2016. 


\section{Introduction}

Central European forests will be affected by climate change (Hemery 2008), resulting in substantial loss of silvicultural importance of some native tree species due to their susceptibility to summer drought (e.g. Kölling et al. 2009; Milad et al. 2013). Thus, the discussion on introduction and cultivation (,,assisted migration") of exotic tree species re-emerges (e.g. Gray et al. 2011; Millar et al. 2007; Reif et al. 2011). Today a substantial part of commercial forestry is based on the cultivation of introduced non-native tree species (Sedjo 1999; Zobel et al. 1987) including Northern Red Oak (Quercus rubra L.). Introduced from North America in 1724, this species is currently the most common exotic broad-leafed tree species in Central European forestry (Schütt et al. 2011). However, nature conservation authorities consider $Q$. rubra an invasive species that causes a negative impact on the native bio-diversity (Kowarik 2010, Nehring et al. 2013, Woziwoda et al. 2014).

An important step in spreading of a plant species is the dispersal of its seeds, which is assisted by animals (Gosper et al. 2005). The majority of acorns of the oak species (Quercus spp.) are heavy and dispersed barochorously or by animals (Ducousso et al. 1993). Due to their high abundance and nutrient content they are attractive as food for many forest vertebrates (den Ouden et al. 2005). Hoarding of acorns in the soil by different animal species is essential in natural regeneration processes of almost all oak species because acorns not retrieved or eaten by other predators can germinate and thus seedlings can establish (Vander Wall 2001). Rodents and some jays are the most important hoarding dispersers. They transport acorns up to $100 \mathrm{~m}$ or in case of the jays even up to several kilometers (Ducousso et al. 1993; den Ouden et al. 2005; Vander Wall 1990, 2001). In its native range in North America, Q. rubra is mainly dispersed by the Blue Jay (Cyanocitta cristata L., Darley-Hill \& Johnson 1981), and to minor extent by rodents 250 such as the Gray Squirrel (Sciurus carolinensis J.F.Gmel, Goheen \& Swihart 2003), the American Fox Squirrel (Sciurus niger L, Short 1976) and the Eastern Chipmunk (Tamias striatus L., Pyare et al. 1993). In Europe, most effective dispersers of the native oaks ( $Q$. robur L. and Q. petraea (MATt.) LieBL.) are the Wood Mouse (Apodemus sylvaticus L.) and the European Jay (Garrulus glandarius L.) whereas pigeons, crows, squirrels and other mice are thought to be of minor importance (den Ouden et al. 2005). The question arises whether European Jays and mice could also disperse acorns of non-indigenous Red Oak in Central Europe. In this context, acorn morphology may play an important role as European Jays select acorns by morphological characteristics (Bossema 1979; Pons \& Pausas 2007).

Myczko et al. (2014) recently showed that European Jays prefer acorns of $Q$. robur (Pedunculate Oak) to Q. rubra ones if they are offered together in a dual choice experiment and tend to pick more Red Oak acorns in late autumn compared to early autumn. They concluded that under limited supply of Pedunculate Oak acorns jays might take more Red Oak ones and thus contribute substantially to long distance seed dispersal. However, it is still ambiguous to what extent jays will collect Red Oak acorns if they are available exclusively and moreover to what extent native rodents contribute to dispersing Q. rubra acorns.

Therefore our study aims at (1) quantifying the morphological differences between acorns of $Q$. rubra and $Q$. robur, (2) in a field experiment, analyzing whether European Jays and mice disperse acorns of Q. rubra, and (3) whether this dispersal depends on choice options for European Jays and mice.

\section{Materials and methods}

\section{Acorn material}

Quercus robur and Q. rubra acorns were collected in October 2012 at 2 sites each species 
and in October 2013 at 10 (Q. robur) and 5 sites $(Q . r u b r a)$ in forest stands and parks within the city limits of Bayreuth. At each site, a minimum of three trees was sampled. All collected acorns were subjected to a flotation test and only sinking (well developed) ones were randomly chosen for investigations. Acorns collected in October 2012 were stored at 12$18{ }^{\circ} \mathrm{C}$ in open plastic bags until gathering dry weight in March 2013. Acorns collected in October 2013 were kept up to four weeks in cloth bags in a refrigerator $\left(-2\right.$ to $\left.+8{ }^{\circ} \mathrm{C}\right)$ before they were used for morphological measurements and selection experiments.

\section{Acorn morphology}

Length (without acorns' foremost tip) and maximum width of 1340 Quercus rubra and 1340 Q. robur acorns were measured with a calliper rule and the acorns were stored again in a refrigerator until they were used for selection experiments. The pericarp thickness was measured in additional 30 acorns per species with the same calliper rule at the acorn's widest point. In addition, 60 acorns of each species were dried at $80{ }^{\circ} \mathrm{C}$ to a constant weight (compartment dryer: Memmert, UL 50) and dry weight was gathered (Lab weighing scale: Mettler Toledo, AE 240).

\section{Acorn selection experiment}

Study site. Field experiments were carried out at the Ecological-Botanical Gardens,
University of Bayreuth, Germany (EBG, 49 $55^{\prime} 45^{\prime}$ " N; $11^{\circ} 35^{\prime} 10^{\prime \prime} \mathrm{E}, 355$ to $370 \mathrm{~m}$ a.s.l.) which is 16 ha in size comprising rather passively managed woodland and grasslands to a large extent. Experiments were conducted from October 18th to November 13th 2013. Acorn yield of native oak species in the Botanical Gardens during that autumn was low. During the experiments there was some precipitation on 6 days (overall sum $9.3 \mathrm{~mm}$, maximum $1.0 \mathrm{~mm} / 10 \mathrm{~min})$. Mean day and night temperature was $10{ }^{\circ} \mathrm{C}$ and $8{ }^{\circ} \mathrm{C}$, respectively. Lowest temperature was $-3{ }^{\circ} \mathrm{C}$ and highest $21^{\circ} \mathrm{C}$ (data from meteorological station at the EBG).

Experimental set up. Acorns of Quercus robur and $Q$. rubra were offered to birds and mice using two types of platforms (see table 1, figure 1). In a first design, acorns of $Q$. rubra and $Q$. robur were offered together (= dual choice experiment). In a second experiment, acorns of either Q. robur or Q. rubra were offered (= no-choice experiment). We selected randomly which of the two oak species was offered on each day. In each set up, 30 randomly chosen acorns per oak species were offered randomly spread on the feeding platforms ( $80 \times 80 \mathrm{~cm}$, figure 1). Each experiment was carried out separately at daytime and at night. Twice a day, at sunset and sunrise, the remaining acorns were removed, counted, and the platforms were loaded again. According to decreasing day length in autumn, exposition time was 10 - $11.5 \mathrm{~h}$ day and 12.5 - $13 \mathrm{~h}$ night, respectively.

Platforms used for birds were constructed as

Table 1 Experimental design for the field experiments

\begin{tabular}{|c|c|c|c|c|c|c|}
\hline \multirow{2}{*}{$\begin{array}{l}\text { Disperser } \\
\text { Experimental type } \\
\text { (choice option) }\end{array}$} & \multicolumn{3}{|c|}{ Jays (table) } & \multicolumn{3}{|c|}{ Mice (tunnel) } \\
\hline & Dual choice & $\begin{array}{l}\text { No-ch } \\
\text { (either } Q \text {. } \\
\text { Q rubra }\end{array}$ & $\begin{array}{l}\text { hoice } \\
\text { robur or } \\
\text { offered) }\end{array}$ & Dual choice & $\begin{array}{r}\text { No-c } \\
\text { (either } Q . \text { rol } \\
\text { off }\end{array}$ & $\begin{array}{l}\text { choice } \\
\text { bur or Q rubra } \\
\text { fered) }\end{array}$ \\
\hline $\begin{array}{l}\text { Number of acorns } \\
\text { per replicate }\end{array}$ & $\begin{array}{c}30 \text { Q. robur }+ \\
30 \text { Q. rubra }\end{array}$ & 30 Q. robur & 30 Q. rubra & $\begin{array}{c}30 \text { Q. robur }+ \\
30 \text { Q. rubra }\end{array}$ & 30 Q. robur & 30 Q. rubra \\
\hline \multirow{2}{*}{$\begin{array}{l}\text { Number of } \\
\text { replicates }\end{array}$} & $\mathrm{n}=9+9$ & $\mathrm{n}=9$ & $\mathrm{n}=9$ & $\mathrm{n}=9+9$ & $\mathrm{n}=9$ & $\mathrm{n}=9$ \\
\hline & $\mathrm{n}=9+9$ & $\mathrm{n}=9$ & $\mathrm{n}=9$ & $\mathrm{n}=9+9$ & $\mathrm{n}=9$ & $\mathrm{n}=9$ \\
\hline Date (year 2013) & Oct $28-31$ & \multicolumn{2}{|c|}{ Oct $18-26$} & Oct $28-31$ & \multicolumn{2}{|c|}{$\begin{array}{l}\text { Oct } 18-26 \text { and } \\
\text { Nov } 8-13\end{array}$} \\
\hline
\end{tabular}



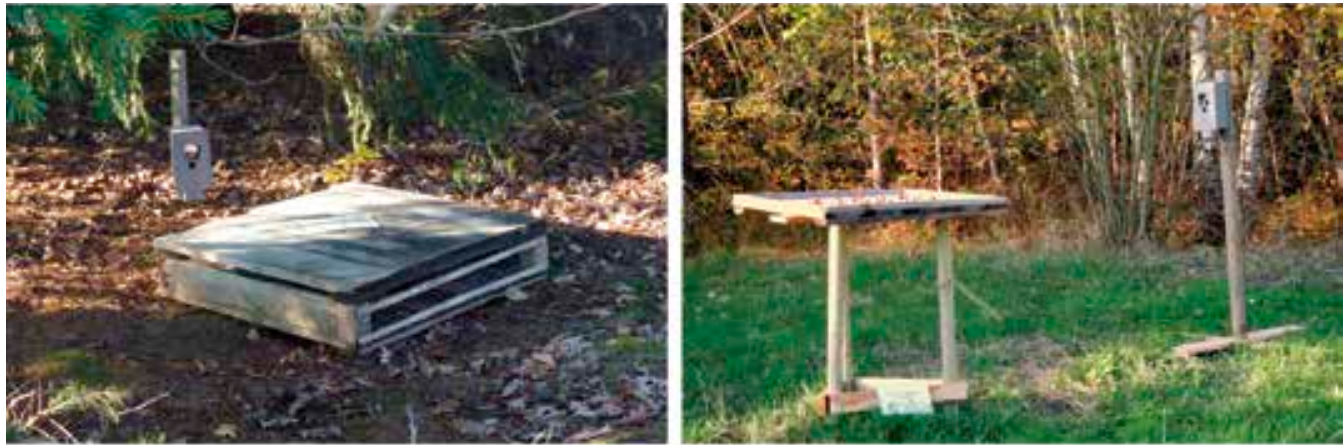

Figure 1 Feeding platforms used for the experiments and installed scouting cameras. Platforms used for mice (left) were constructed as tunnels, platforms used for birds (right) as tables

tables (figure 1), placed one meter above the ground with three posts in the center of the table preventing mice and other mammals to climb or jump it. The tables were placed on a meadow, freestanding but with woodland in the background. Platforms used for mice were formed as a tunnel (figure 1) placed on the ground in shrubs or woodlands, having a height of ten centimeter and a removable lid for putting acorns into it. Two opposite sides of the tunnel were closed by a plank, the other two by a broad-meshed chicken wire to allow only mice to enter. There were three platforms of each kind, and each platform was used for three replicates. Each day all platforms were placed at another of three preselected sites at the Botanical Gardens. Distance between platforms at each site was in the minimum $55 \mathrm{~m}$. Scouting cameras were installed at two platforms of each kind, one camera working with a white flash (Cuddeback Capture, Model 1125) and one with an infrared flash (Cuddeback Attack IR, Model 1156). Photographed animals were identified as exactly as possible according to Corbet \& Ovenden (1982).

\section{Data analysis}

With the help of a linear model we tested whether the number of removed acorns depends on oak species, disperser, daytime, their pairwise interactions, the choice option (nochoice and dual choice respectively), and the interaction of choice option with the disperser group (birds and mice). Furthermore, for each disperser group, oak species (Q. rubra and $Q$. robur) and daytime (day or night) it was tested by Mann-Whitney-U-test whether there were differences regarding the number of removed acorns between no-choice and dual choice experiment. Because there were no differences between them and the linear model showed no significant effect of choice option (see table 2, 3 in results), data of both experiments were pooled for the analysis, whether there are differences in the acorn removal between oak species, disperser and daytime (Kruskal-Wallis- and posthoc pairwise Mann-Whitney-Utest with Bonferroni correction). Differences in morphological parameters between Quercus rubra and $Q$. robur were analyzed by a MannWhitney-U-test.

Data analysis was done with the software package R (R Core Team, 2013), RStudio version 0.97 .551 and additionally the package $s c i$ plot (Morales 2012). For creating figures, the graphic programs Inkscape 0.48 and gimp 2.8 were used.

\section{Results}

\section{Acorn morphology}

Acorns of Quercus robur and Q. rubra were significantly different in all morphological pa- 
rameters measured (figure 2). Q. rubra acorns were $2.3 \mathrm{~cm}$ long and $1.9 \mathrm{~cm}$ wide (figure 2 $\mathrm{a}, \mathrm{b})$, therefore clearly shorter and wider than those of $Q$. robur and thus of a rounder shape (figure $2 \mathrm{c}$ ). $4.9 \%$ of the Red Oak acorns were even wider than long (shape $<1$ ), which never was the case in $Q$. robur. On the other hand $14 \%$ of $Q$. robur acorns are more than twice as long as wide, which never was found in $Q$. rubra. The pericarp of $Q$. rubra acorns was 3.5 times thicker than that of $Q$. robur (figure $2 \mathrm{~d}$ ). Further acorns of $Q$. rubra were heavier (dry weight $3.4 \mathrm{~g}$ ) than $Q$. robur ones (figure $2 \mathrm{e}$ ). The appearance of acorns was also different for both species. Fresh $Q$. rubra acorns were more or less dark reddish brown and covered with a thin furry coating, which came off by and by. In contrast the surface of $Q$. robur acorns was glabrous, rather pale and ochre with typical dark longitudinal stripes.

\section{Acorn selection by mice and jays}

Installed scouting cameras documented only European Jays (Garrulus glandarius, see figure 3 ) at the tables (38 shots) and only mice at the tunnels (661 shots). Finally it is evident that the tunnel platforms were specific to mice and the tables to jays as potential acorn dispersers. About half of the visiting mice were identified either as Apodemus sylvaticus (Wood Mouse) or as Apodemus flavicollis MelchIor (Yellow-Necked Mouse, see figure 3). The photos taken did not allow to distinguish between these two taxa. Only 12 photographs pictured mice with small ears and shorter tail being characteristic of Clethrionomys glareolus Schreber (Bank Vole), Microtus arvalis PALLAS (Common Vole) and Pitymys subterraneus de SÉlys Longchamps (European Pine Vole). On the remaining photos it was not possible to detect species specific traits.

Removal of acorns depended on daytime, disperser, oak species and their pairwise interactions (table 2). Mice and jays differed in their activity regarding daytime (interaction disperser $*$ daytime) and in their preferences

Table 2 Results of a linear model: Influence of the tested parameters on the number of removed acorns

\begin{tabular}{lrr}
\hline Parameter & Estimate & $p$-value \\
\hline disperser & 104.5 & $<0.001$ \\
daytime & 28.9 & $<0.001$ \\
oak species & 24.8 & $<0.001$ \\
choice option & -1.1 & 0.839 \\
daytime * disperser & -118.1 & $<0.001$ \\
oak species * daytime & 45.9 & $<0.001$ \\
oak species * disperser & -32.8 & $<0.001$ \\
choice option * disperser & 6.1 & 0.431 \\
\hline
\end{tabular}
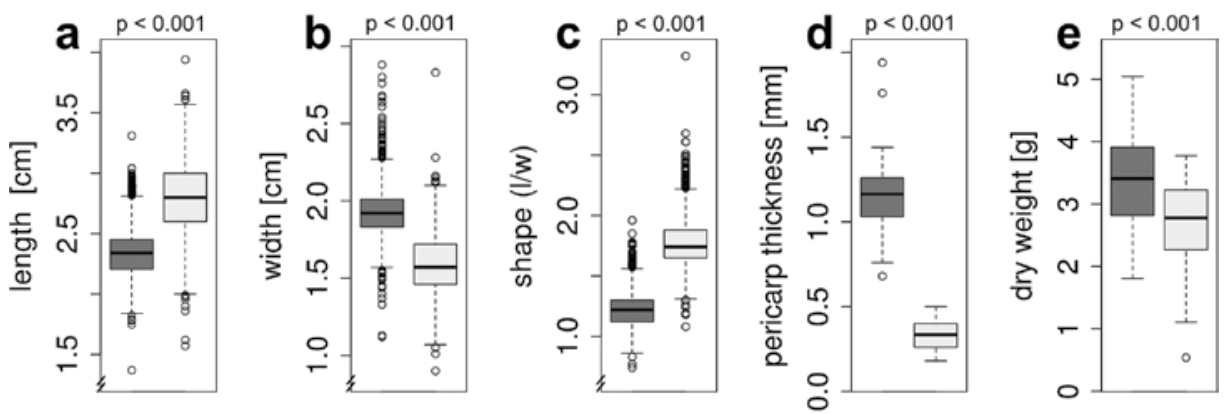

Q. rubra

Q. robur

Figure 2 Morphological characteristics of acorns of Quercus rubra and Q. robur: Length (a, $n=1430)$, width (b, $n=1430)$, shape (length/width, c, $n=1430)$, pericarp thickness $(\mathrm{d}, n=30)$ and dry weight $(\mathrm{e}, n=60)$. Median and quartiles are given, open dots represent outliers. Significant differences where determined by a Mann-Whitney-U-test. 

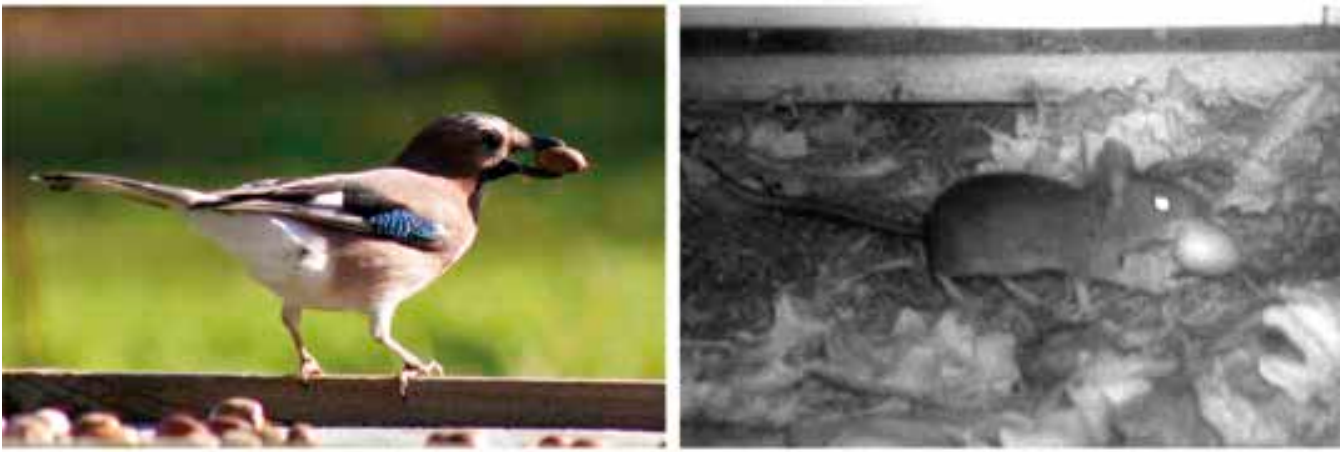

Figure 3 European Jay (left, on a table platform) and a mouse (right, possibly Apodemus sylvaticus or A. flavicollis, in a tunnel platform). Photo on the left was taken by hand, the other at night by a scouting camera

for the acorns of the two oak species (interaction disperser * oak species). Jays took acorns only by day, removing nearly all acorns of Quercus robur, but hardly ever picking $Q$. rubra acorns (about $4 \%$, figure 4). Mice took almost all acorns at night, and about $25 \%$ by day. They did not distinguish between acorns of the two oak species (figure 4). In total, mice carried off more acorns than jays.

The choice option, whether fruits of both oak species were offered together (dual choice) or separately (no-choice), had no significant effect on amount of acorns per oak species removed, neither for jays nor for mice (table 3), and there was no interaction of the choice option and the disperser (table 2). However, for jays there was a slight but insignificant tendency for taking more Q. rubra acorns in the dual choice than in the no-choice option (table 3 ).

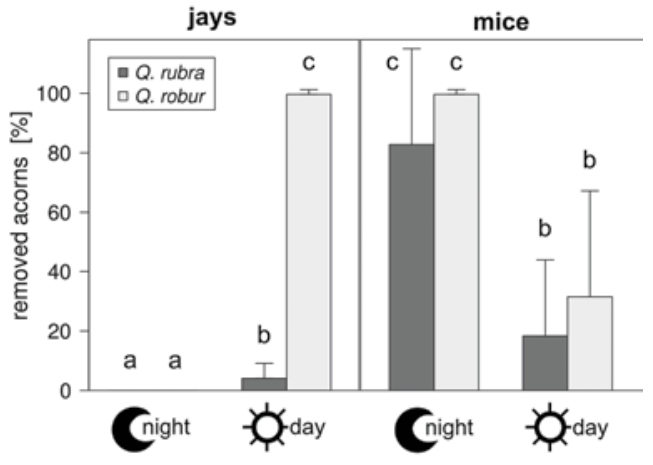

Figure 4

Percentage of removed acorns depending on disperser (jays vs. mice), daytime (night vs. day) and oak species (Quercus rubra vs. Q. robur). Each time 30 acorns per species were offered. Data of no-choice and dual choice experiment were pooled. Mean and standard deviation are given $(\mathrm{n}=18)$. Significant differences are indicated by different lower case letters (pairwise Mann-Whitney-U-test with Bonferroni correction)

\section{Discussion}

Table 3 Results of selection experiments (dual choice vs. no-choice option)

\begin{tabular}{|c|c|c|c|c|c|}
\hline & & & \multicolumn{2}{|c|}{ Percentage of removed acorns (mean $\pm \mathrm{sd}$ ) } & \multirow{2}{*}{$p$-value } \\
\hline & & & Dual choice & No-choice & \\
\hline \multirow{4}{*}{ Jay } & \multirow{2}{*}{ Night } & Q. rubra & $0.0 \pm 0.0$ & $0.0 \pm 0.0$ & -- \\
\hline & & Q. robur & $0.0 \pm 0.0$ & $0.0 \pm 0.0$ & -- \\
\hline & \multirow{2}{*}{ Day } & Q. rubra & $5.9 \pm 5.7$ & $2.2 \pm 3.7$ & 0.142 \\
\hline & & Q. robur & $100.0 \pm 0.0$ & $99.3 \pm 2.2$ & 0.374 \\
\hline \multirow{4}{*}{ Mice } & \multirow{2}{*}{ Night } & Q. rubra & $84.8 \pm 30.4$ & $80.7 \pm 35.6$ & 0.737 \\
\hline & & Q. robur & $99.3 \pm 2.2$ & $100.0 \pm 0.0$ & 0.374 \\
\hline & \multirow{2}{*}{ Day } & Q. rubra & $10.4 \pm 16.0$ & $26.3 \pm 31.4$ & 0.636 \\
\hline & & Q. robur & $27.8 \pm 30.8$ & $35.2 \pm 41.6$ & 0.644 \\
\hline
\end{tabular}




\section{European Jays avoid acorns of introduced Quercus rubra}

Our results confirm that jays prefer acorns of Quercus robur, when they are allowed to choose between the acorns of native $Q$. robur and North American Q. rubra, as already shown by Bossema (1979) and Myczko (2014). In addition we demonstrated that Red Oak acorns are generally largely unattractive for jays as they even were mostly ignored when they were offered alone. It is known that European Jays swallow up to five acorns in their esophagus and carry one in the bill and therefor they prefer long and slim ones (Bossema 1979). As we measured, acorns of Q. rubra were clearly shorter, wider and heavier than those of $Q$. robur, which may cause problems for transport and may explain why jays avoid these exotic acorns. Because of throat limitation the upper width for swallowing an acorn is stated as $1.9 \mathrm{~cm}$ (Pons \& Pausas 2007), being exactly the median of $Q$. rubra acorns' width we measured. Thus half of all Red Oak acorns are likely to wide to be swallowed by jays. Furthermore jays may select acorns visually by color and shell texture (Bossema 1979; Pons \& Pausas 2007). Acorns of Q. rubra are darker, more pubescent and less shiny than the ones of $Q$. robur and therefore both species may be distinguished easily by jays. Considering that jays seem to be able to identify damaged acorns by their consistency (Bossema 1979; Pons \& Pausas 2007), we assume that they are also able to discriminate between acorns of Q. rubra and $Q$. robur cause of their different shell thickness. Additionally the thick shell of Q. rubra acorns makes them difficult to husk (Bossema 1979). Even the Blue Jay (Cyanocita cristata), an important disperser of Q. rubra in North America (Darley-Hill \& Johnson 1981), favors acorns of Quercus species with thinner walls and of smaller size compared to $Q$. rubra acorns, which are only taken when other acorns are scarce (Moore \& Swihart 2006). Hence it is important whether European Jays would be- have similar and take more acorns of $Q$. rubra when alternative food is scarce, e.g. during winter or if fruit set of the native oaks is low. Myczko et al. (2014) found that more Q. rubra acorns were removed by European Jays in late than in early autumn and explained this observation with decreasing acorn availability over the autumn. But this conclusion seems untenable considering our results. Even if only Q. rubra fruits were supplied, jays tended to take even less of these acorns compared to the dual choice experiment, which indicates the low attractiveness of Red Oak acorns for jays even without an offered alternative. However, we assume that jays cannot distinguish perfectly between acorns of both species and take $Q$. rubra acorns accidentally when collecting those of $Q$. robur. Given that European Jays hardly take acorns of introduced $Q$. rubra, long distance dispersal of this species should be low because jays are by far the most important long distance dispersers (up to several kilometers) of acorns in Central Europe (Gomez 2003; den Ouden et al. 2005). Nevertheless, since they take $Q$. rubra acorns in rare cases, they may contribute to some long distance dispersal resulting in founding of new populations as well.

\section{Mice take acorns of exotic and native oak likewise}

In contrast to jays mice did not select between acorns of both Quercus species. Obviously different acorn morphology of the two oak species is no selection criterion for mice. Mice should be able to carry both clenching them between their teeth, and obviously the higher dry weight of $Q$. rubra acorns is not hindering. Furthermore, considering that mice can even crack the hard shell of hazelnuts, their nimble handling and opening of the thick pericarp of Red Oak acorns would not come as a surprise. Nevertheless, the number of exotic acorns transported by mice is notable. In their study on Mediterranean oaks Pons \& Pausas (2007b) found some acorn selection 
by mice regarding the oak species whereby they tended to prefer heavier acorns. This is consistent with our finding that the mice did not avoid the heavier acorns of Q. rubra. It is known that rodents select seeds olfactorily and by chemical compounds (Steele et al. 2001). Acorns of the red oak section (Lobatae) have a high tannin and lipid contents in contrast to the white oak section ones (Quercus), including the Central European oak species (Nixon 1993; Smallwood et al. 2001). Tannins cause a bitter taste, affect digestion and are a chemical defense against predators (Vander Wall 2001). Studies on North American squirrels and chipmunks found preference for acorns of the white oak section over acorns of the red oak section (incl. Q. rubra) due to their lower tannin content (Pyare et al. 1993; Short 1976). On the other hand, high tannins prevent insect infestation (Smallwood et al. 2001) and the high nutritive lipid content can reduce the negative effect of tannins on acorn preference (Smallwood \& Peters) and can make seeds more attractive for rodents (Ivan \& Swihart 2000), which may lead to preferential caching and even a better dispersal of acorns of the red oak section (Smallwood et al. 2001). Beside the controversial discussion how those tannins and lipids affect the selection behavior of rodents, our results gave no indication that mice select between native $Q$. robur and introduced Q. rubra.

Rodents are generally considered to be less effective in dispersing seeds than jays, because of relative low dispersal distances (Ducousso et al. 1993; Gomez et al. 2008; Jensen \& Nielsen 1986) and because they are important acorn predators (Ducousso et al. 1993; Gomez et al. 2008). Sork (1984) found North American rodents dispersing acorns of Q. rubra up to $20 \mathrm{~m}$, but with a predation rate of $99 \%$. Similar patterns were revealed for two Apodemus and two oak species in Japan (Iida 1996). In Central Europe however, the Wood Mouse (Apodemus sylvaticus) is considered to be a quite effective acorn disperser (den Ouden et al. 2005). Although it hoards the seeds at a mean distance 256 of only $7.5 \mathrm{~m}$, several relocating events can finally lead to much higher dispersal distances (den Ouden et al. 2005). In Danish heathlands Apodemus sylvaticus, A. flavicollis and other mice mediated a rapid colonization with native oaks (Jensen \& Nielsen 1986). These two mice species were the most frequent ones observed in our study, which, as we have shown, took the same amount of acorns of $Q$. rubra and Q. robur. Additionally and in contrast to the European Jay, Wood Mice store the acorns in habitats with closer vegetation which provide better protection against herbivores but lower light availability for the seedlings (den Ouden et al. 2005). For $Q$. rubra, which is regarded as an intermediate shade tolerant species (Sander 1990), this would even be an advantage compared to the shade intolerant $Q$. robur (Schütt et al. 2011). Overall, mice are quite effective dispersers of the Red Oak acorns.

\section{Conclusion}

Quercus rubra, regarded as an invasive species in Central Europe (Kowarik 2010; Nehring et al. 2013), regenerates naturally in its new environment. We tested whether Central European animals are effective seed dispersers of this introduced species. Regarding the acorn collecting behavior of mice and jays observed in our study we conclude that $Q$. rubra is dispersed quite well. The results indicate minor dispersal of $Q$. rubra over long distances by European Jays but an intense dispersal over moderate distances mediated by mice. In general this promotes local regeneration and increases population size and stability rather than advancing colonization of new sites as long distance transport do (Gomez 2003; Vander Wall 2001). We suggest that the spread of the introduced $Q$. rubra is also favored by other additional factors as dispersal e.g. low mildew infection of the leaves or low insect damage of the acorns (Goßner \& Gruppe 2004; Goßner \& Simon 2005). 


\section{Acknowledgements}

We thank the Naturpark Fichtelgebirge for lending the scouting cameras, Wolfgang Völkl for developing the platforms, Andreas Schweiger for assistance in experimental design and statistical analysis, Gesa Thomas for linguistic advice on the manuscript and Prof. Stefan Dötterl for his comments that greatly improved the manuscript.

\section{References}

Bossema I., 1979. Jays and oaks: an eco-ethological study of a symbiosis. Behaviour 70: 1-117.

Corbet G., Ovenden D., 1982. Pareys Buch der Säugetiere - Alle wildlebenden Säugetiere Europas. Paul Parey, Hamburg and Berlin, $240 \mathrm{p}$.

Darley-Hill S., Johnson W.C., 1981. Acorn dispersal by the blue jay (Cyanocitta cristata). Oecologia 50(2): 231-232. DOI: 10.1007/BF00348043.

Ducousso A., Michaud H., Lumaret R., 1993. Reproduction and gene flow in the genus Quercus L.. Annales des sciences forestières 50: 91s-106s. DOI: 10.1051/ forest: 19930708 .

Goheen J.R., Swihart R.K., 2003. Food-hoarding behavior of gray squirrels and North American red squirrels in the central hardwoods region: implications for forest regeneration. Canadian Journal of Zoology 81(9): 16361639. DOI: 10.1139/Z03-143.

Gomez J.M., 2003. Spatial patterns in long-distance dispersal of Quercus ilex acorns by jays in a heterogeneous landscape. Ecography 26(5): 573-584. DOI: 10.1034/j.1600-0587.2003.03586.x.

Gomez J.M., Puerta-Piñero C., Schupp E.W., 2008. Effectiveness of rodents as local seed dispersers of Holm oaks. Oecologia 155(3): 529-537. DOI: 10.1007/ s00442-007-0928-3.

Gosper C.R., Stansbury C.D., Vivian-Smith G., 2005. Seed dispersal of fleshy-fruited invasive plants by birds: contributing factors and management options. Diversity and Distributions 11(6): 549-558. DOI: 10.1111/j.13669516.2005.00195.x.

Goßner M., Gruppe A., 2004. Infestation of indigenous (Quercus robur) and introduced oaks (Quercus rubra) by seed insects - interaction of plant compounds and larvae development. Mitteilungen der Deutschen Gesellschaft für allgemeine und angewandte Entomologie 14(1-6): 41-44.

Goßner M., Simon U., 2005. Effect of introduced Red oak (Quercus rubra L.) on a specialised phytophagous guild in Germany - a case study of seed infesting insects (Coleoptera, Lepidoptera). NeoBiota 6: 89-109.
Gray L.K., Gylander T., Mbogga M.S., Chen P.Y., Hamann A., 2011. Assisted migration to address climate change: recommendations for aspen reforestation in western Canada. Ecological Applications 21(5): 15911603. DOI: $10.1890 / 10-1054.1$.

Hemery G.E., 2008. Forest management and silvicultural responses to projected climate change impacts on European broadleaved trees and forests. International Forestry Review 10(4): 591-607. DOI: 10.1505/ifor.10.4.591.

Iida S., 1996. Quantitative analysis of acorn transportation by rodents using magnetic locator. Vegetatio 124(1): 39-43. DOI: 10.1007/BF00045142.

Ivan J.S., Swihart R.K., 2000. Selection of mast by granivorous rodents of the central hardwood forest region. Journal of Mammalogy 81(2): 549-562. DOI: 10.1644/1545-1542(2000)081<0549: SOMBGR>2.0. $\mathrm{CO} ; 2$.

Jensen T.S., Nielsen O.F., 1986. Rodents as seed dispersers in a heath-oak wood succession. Oecologia 70(2): 214-221. DOI:10.1007/BF00379242.

Kölling C., Knoke T., Schall P., Ammer C., 2009. Überlegungen zum Risiko des Fichtenanbaus in Deutschland vor dem Hintergrund des Klimawandels [Considerations about the risk of spruce cultivation in Germany in the light of global change]. Forstarchiv 80(2): 42-54.

Kowarik I. 2010. Biologische Invasionen. Neophyten und Neozoen in Mitteleuropa [Biological invasions. Neophytes and neozoans in Central Europe]. 2nd edn, Eugen Ulmer, Stuttgart, $492 \mathrm{p}$.

Milad M., Schaich H., Konold W., 2013. How is adaptation to climate change reflected in current practice of forest management and conservation? A case study from Germany. Biodiversity and Conservation 22(5): 1181-1202. DOI: 10.1007/s10531-012-0337-8.

Millar C.I., Stephenson N.L., Stephens S.L., 2007. Climate change and forests of the future: managing in the face of uncertainty. Ecological applications 17(8): 2145-2151. DOI: 10.1890/06-1715.1.

Moore J.E., Swihart R.K., 2006. Nut selection by captive blue jays: importance of availability and implications for seed dispersal. Condor 108: 377-388. DOI: 10.1650/0010-5422(2006)108[377:NSBCBJ]2.0.CO;2.

Morales M., with code developed by the R Development Core Team, with general advice from the R-help listserv community and especially Duncan Murdoch., 2012. sciplot: Scientific Graphing Functions for Factorial Designs. R package version 1.1-0.

Myczko Ł., Dylewski Ł., Zduniak P., Sparks T.H., Tryjanowski P., 2014. Predation and dispersal of acorns by European Jay (Garrulus glandarius) differs between a native (Pedunculate Oak Quercus robur) and an introduced oak species (Northern Red Oak Quercus rubra) in Europe. Forest Ecology and Management 331: 3539. DOI: 10.1016/j.foreco.2014.07.027.

Nehring S., Kowarik I., Rabitsch W., Essl F., 2013. Naturschutzfachliche Invasivitätsbewertungen für in Deutschland wild lebende gebietsfremde Gefäßpflanzen [Conservation assessment of the invasiveness of 
wild alien vascular plants in Germany]. BfN-Skripten 352. Bundesamt für Naturschutz, Bonn, 202 p.

Nixon K.C., 1993. Infrageneric classification of Quercus (Fagaceae) and typification of sectional names. Annales des sciences forestières 50: $25 \mathrm{~s}-34 \mathrm{~s}$.

Ouden J. den, Jahnsen P.A., Smit R., 2005. Jays, mice and oaks: predation and dispersal of Quercus robur and Q. petraea in North-western Europe. In: Forget P-M., Lambert J.E., Hulme P.E., Vander Wall S.B. (eds.), Seed fate: predation, dispersal and seedling establishment. CABI Publishing, Wallingford, pp. 223-239.

Pons J., Pausas J.G., 2007a. Not only size matters: Acorn selection by the European jay (Garrulus glandarius). Acta Oecologica 31(3): 353-360. DOI:10.1016/j. actao.2007.01.004.

Pons J., Pausas J.G., 2007b. Rodent acorn selection in a Mediterranean oak landscape. Ecological Research 22(4): 535-541. DOI: 10.1007/s11284-006-0053-5.

Pyare S., Kent J.A., Noxon D.L., Murphy M.T., 1993. Acorn preference and habitat use in eastern chipmunks. American Midland Naturalist, 130(1): 173-183.

R Core Team, 2013. R: A language and environment for statistical computing. R Foundation for Statistical Computing, Vienna, Austria.

Reif A., Aas G., Essl F., 2011. Braucht der Wald in Zeiten der Klimaveränderung neue, nicht heimische Baumarten? [Does the forest in times of global change need new exotic tree species?] Natur und Landschaft 86(6): 256-260.

Sander I.L., 1990. Quercus rubra L. In: Burns, Russell M., and Barbara H. Honkala (tech. coords.), Silvics of North America: 2. Hardwoods. Agriculture Handbook 654, vol.2, U.S. Department of Agriculture, Forest Service, Washington, DC. Web: http:/www.na.fs.fed. us/spfo/pubs/silvics_manual/volume_2/quercus/rubra. htm. Accessed 18 March 2015.

Schütt P., Schuck H.J., Stimm B., 2011. Lexikon der Baum- und Straucharten. Das Standardwerk der Forstbotanik. Morphologie, Pathologie, Ökologie und Syste- matik wichtiger Baum- und Straucharten [Enzyclopedia of tree and shrub species. The standard work of forest botany. Morphology, pathology, ecology and systematics of important tree and shrub species.]. Genehmigte Lizenzausgabe Nikol. Verlagsgesellschaft, Hamburg, $581 \mathrm{p}$.

Sedjo R.A., 1999. The potential of high-yield plantation forestry for meeting timber needs. Forestry Sciences 56 : 339-359. DOI: 10.1007/978-94-017-2689-4_21.

Short H.L., 1976. Composition and squirrel use of acorns of black and white oak groups. Journal of Wildlife Management 40(3): 479-483. DOI: 10.2307/3799950.

Smallwood P.D., Peters W.D., 1986. Grey squirrel food preferences: the effects of tannin and fat concentration. Ecology 67(1): 168-174. DOI: 10.2307/1938515.

Smallwood P.D., Steele M.A., Faeth S.H., 2001. The ultimate basis of the caching preferences of rodents, and the oak-dispersal syndrome: tannins, insects, and seed germination. American Zoologist 41(4): 840-851. DOI: 10.1093/icb/41.4.840

Sork V.L., 1984. Examination of seed dispersal and survival in red oak, Quercus rubra (Fagaceae), using metal-tagged acorns. Ecology 65(3): 1020-1022. DOI: $10.2307 / 1938075$.

Steele M.A., Smallwood P.D., Spunar A., Nelsen E., 2001. The proximate basis of the oak dispersal syndrome: detection of seed dormancy by rodents. American Zoologist 41(4): 852-864. DOI: 10.1093/icb/41.4.852.

Vander Wall S.B., 1990. Food hoarding in animals. University of Chicago Press, Chicago and London, 445 p.

Vander Wall S.B., 2001. The evolutionary ecology of nut dispersal. The Botanical Review 67(1): 74-117. DOI: 10.1007/BF02857850.

Woziwoda B., Kopeć D., Witkowski J., 2014. The negative impact of intentionally introduced Quercus rubra L. on a forest community. Acta Societatis Botanicorum Poloniae 83(1): 39-49. DOI: 10.5586/asbp.2013.035.

Zobel B.J.G., van Wyk G., Stahl P., 1987. Growing exotic forests. New York, NY: Wiley, 508 p. 